\title{
BIOCHEMICAL STUDIES ON Q-AMYLASE INHIBITOR EXTRACTED FROM WHITE KIDNEY BEAN (Phaseolus vulgaris)
}

Tadros, L.K.; N.S. Eryan; A.M. Yussef and Nancy A.A. Taha

Dept. of Agric. Chemistry, Faculty of Agriculture, Mansoura University, Egypt.

\begin{abstract}
Crude extract of white kidney beans (Phaseolus vulgaris) showed inhibitory activity against porcine pancreatic $\alpha$-amylase and human salivary $\alpha$-amylase. Alpha amylase inhibitors are substances which alter the catalytic action of alpha amylase on starch and consequently slow down or stop the breakdown of starch. The obtained extract was examined qualitatively for phytochemical constituents and total protein content was determined by Lowry method. The crude extract was also studied for $\alpha$ amylase inhibition activity which showed a linear relationship between the percentage of inhibition and inhibitor concentrations. Optimum temperature was $37^{\circ} \mathrm{C}$, optimum periods for preincubation and incubation were 15 and 60 min. Nearly $90 \%$ of inhibition was occurred after 60 min from the beginning of incubation. Kidney bean crude extract inhibits porcine pancreatic $\alpha$-amylase and human saliva $\alpha$-amylase in a non-competitive manner.
\end{abstract}

Keywords: Inhibitor, Alpha- amylase, kidney beans, non-competitive inhibition.

\section{INTRODUCTION}

Phaseolus vulgaris comprises several varieties of beans: white, black, pinto, navy, and northen beans, (Duke 1985).

Amylase inhibitors (also known as starch blockers) have been used to promote weight loss in over weight individuals. The initial amylase inhibitors are not very effective in limiting carbohydrate absorption, (Bo-linn et al., 1982; Carlson et al., 1983; Garrow et al., 1983 and Hollenbeck et al., 1983). However, development of highly concentrated versions of amylase inhibitors, including the extract of the white kidney bean resulted in more potent $\alpha$-amylase inhibiting activity in vitro (Layer et al., 1986). More effective inhibition of carbohydrate absorption have been showed in humans (Layer et al., 1985; Boivin et al., 1987 and Brugge and Rosenfeld 1987).

Diabetes mellitus is one of the world's major diseases, with an estimation of 347 million adults affected in 2011 (Danaei et al., 2011). Type 2diabetes mellitus, by far the most common type, is a metabolic disorder of multiple etiology characterized by carbohydrate, lipid and protrein metabolic disorders that includes defect in insulin secretion, almost always with a major contribution of insulin resistance (Alberti and Zimmet, 1998). These abnormalities could lead to lesion such as retinopathy, neuropathy and angiopathy, (Holman et al., 2008). The inhibition of carbohydrate digestive enzymes is considered a therapeutic tool for the treatment of type 2 diabetes (Tundis et al., 2010). The most important digestive enzyme is pancreatic alpha-amylase (EC 3.2.1.1), a calcium metalloenzyme that catalyses the hydrolysis of the alpha-1, 4 glycosidic linkages of starch, amylase, 
amylopectin, glycogen and various maltodextrins and is responsible of most of starch digestion in humans.

Common beans have 3-isoforms of alpha amylase inhibitor (AlphaA1, Alpha-A2, and Alpha-A1L). The alpha-A1 isoform has anti-amylase activity in humans. Alpha-amylase inhibitors with activity against mammalian forms of the enzyme are present in plants and it is suggested that they were developed by plants in order to strengthen their defense against predators.

Plant constituents with enzymatic inhibitory activity include polyphenolic compounds and glycoproteins (Tundis et al., 2010 and Moreno et al., 1990). For example, anthocyanins and ellagitannins present in raspberries and strawberries have been reported to inhibit alpha-glucosidase and alpha-amylase activity, respectively, (McDougal and Stewart, 2005). In addition, flavins and catechins present in green and black teas have been reported to inhibit alpha-amylase and alpha-glucosidase activity as well as retard starch digestion in an in-vitro model, (Koh et al., 2010). Alpha-amylase inhibitors are also present in grains, including wheat and rice (Tundis et al., 2010). However, the greatest body of research has gone into glycoproteins extracted from kidney beans (Phaseolus vulgaris) and more specifically on the proprietary phase 2 product. Weiner et al., (2008) stated that salivary alpha-amylase activity showed a significant inhibition following exposure to cigarette smoke and this may be due to the interaction between aldehydes which present in cigarette smoke and $-\mathrm{SH}$ groups of the enzyme. The objective of this study was to evaluate the $\alpha$-amylase inhibitory potential of $P$. vulgaris extract.

\section{MATERIALS AND METHODS}

\section{Materials:}

1. White kidney beans ( Phaseolus vulgaris) were purchased from the local market.

2.Porcine pancreatic $\alpha$-amylase (PPA) was obtained from Sigma Chemical Company, ST. LOUIS, U.S.A.

3. Human saliva a-Amylase.

4. Soluble starch.

Methods:

Preparation of crude $\alpha$-amylase inhibitor:

$\alpha$ - Amylase inhibitor, crude extract,was extracted from white kidney bean as suggested by Yamaguchi (1991). $\alpha$ - Amylase inhibitor was extracted in a solution of $\mathrm{NaCl}$ followed by ammonium sulphate precipitation, resulted

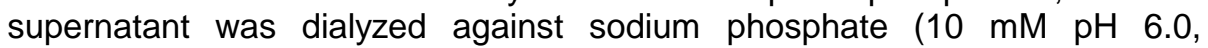
containing $15 \%$ ammonium sulphate). Obtained extract was kept at $4^{\circ} \mathrm{C}$ for further analysis.

\section{Preliminary Phytochemical Screening:}

Crude extract of the a-amylase inhibitor was screened for the presence of various phytoconstituents, namely: Tannins, alkaloids, saponins, carbohydrates and /or glucosides and proteins as described in Harbone (1988). 


\section{Determination of protein:}

Protein concentration of $\alpha$-amylase inhibitor was determined using the method of Lowry et al. (1951).

Alpha-amylase inhibition assay:

The $\alpha$-amylase inhibitory activity for the crude extract was determined spectrophotometrically assay as reported by Hossain et al. (2008). Known volumes of the crude extract $(100,200,300,450$ and $600 \mu \mathrm{l})$ were completed to a total volume of $780 \mu \mathrm{l}$ by the addition of phosphate buffer 20 $\mathrm{mM} \mathrm{pH} 6.9$ containing $6 \mathrm{mM}$ sodium chloride. Porcine pancreatic $\alpha$-amylase solution (10 $\mu$ l containing 0.4 units) was added, separately. Samples were preincubated at $37^{\circ} \mathrm{C}$ for $15 \mathrm{~min}$, then $200 \mu \mathrm{l}$ of $1 \%$ buffered starch solution were added and the mixture was re-incubated for $1 \mathrm{~h}$. lodine solution $1 \%$ $\left(\mathrm{I}_{2} / \mathrm{KI}\right)$ was added $(100 \mu \mathrm{l})$, followed by $5 \mathrm{ml}$ of distilled water. Absorbance of the obtained colour was measured at $565 \mathrm{~nm}$.

Percentage of inhibition was calculated from the equation:

$$
\% \text { of inhibition }=(A-C) /(B-C) \times 100
$$

Where: $\mathrm{A}=$ absorbance of the sample, $\mathrm{B}=$ absorbance of blank (containing no enzyme) and $\mathrm{C}=$ absorbance of control (containing no starch). Evaluation the Type of inhibition:

Type of inhibition was evaluated for porcine pancreatic $\alpha$-amylase and human saliva $\alpha$-amylase.

1.Crud Extract of $\alpha$-Amylase Inhibitor:

Previously obtained extract from kidney bean was used during this investigation.

\section{Enzyme assay:}

Enzyme activity (for both enzymes) was estimated according to Marshall and Lauda (1975), by determination of released reducing sugars from starch as specific substrate. The released reducing sugars were determined by the method of Somogi (1952).

3. Effect of substrate concentration on the velocity of enzymatic activity:

Enzyme activity was assayed using three different concentrations of starch, i.e. $2.5 \mathrm{mg}, 6.25 \mathrm{mg}$ and $12.5 \mathrm{mg}$ as specific substrate for porcine pancreatic $\alpha$-amylase and human saliva $\alpha$-amylase. Enzyme activity was determined in the absence and in the presence of $100 \mu \mathrm{l}$ and $150 \mu \mathrm{l}$ of enzyme inhibitor. The obtained results were used to realize Michaelis and Menten equation (1913). Lineweaver and Burk method (1934) was used to evaluate the type of inhibition.

\section{Stoichiometry of inhibition:}

The stoichiometry of inhibitor-amylase interaction was investigated as described by Marshall and Lauda (1975) with a slight modification for the determination of remaining substrate (1\% buffered starch) as follows: Porcine pancreatic $\alpha$-amylase was added to the crude inhibitor extract in digest

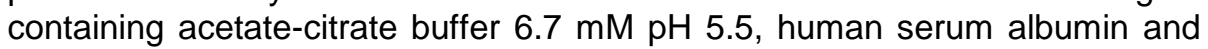
calcium chloride. Residual of $\alpha$-amylase activity was determined after durations of preincubation by addition of buffered starch solution; samples were removed for iodine staining measurements. 
The formula postulated by Bird and Hopkins (1954) was used to calculate the percentage of inhibition as follows:

$\%$ of inhibition $=\mathrm{D}\left[\mathrm{R}_{0}-\mathrm{R}\right] / \mathrm{R}_{0} \times 100$

Where: $\mathrm{R}_{0}=$ Absorbance of substrate-iodine complex in the absence of enzyme ( $E=680 \mathrm{~nm}), R=$ Absorbance of digest (at the same wave length), and $\mathrm{D}=$ Dilution factor of enzyme.

\section{RESULTS AND DISCUSSION}

Earlier reports (Hernandez and Jaffe, 1968 and Bowman, 1945), have indicated that specific proteinaceous inhibitors of a-amylase are widespread in kidney beans (Phaseolus vulgaris) and other legumes. Since $\alpha$-amylase plays an important role in starch breakdown in human beings and animals, the presence of such inhibitors in foodstuffs may be responsible for impaired starch digestion.

a-Amylase inhibitors may be valuable as novel therapeutic and dietetic agents ( Puls and Keup, 1973).

The obtained extract from white kidney bean after dialysis is considered as the crude extract of $\alpha$-amylase inhibitor.

The results of the phytochemical screening conducted on the extract of kidney bean are present in table (1).

Obtained data showed the presence of: tannins, saponins, alkaloids, carbohydrates and / or glycosides and proteins.

Table (1). Phytochemical constituents of $\alpha$-Amylase Inhibitor crude extract.

\begin{tabular}{|l|c|c|c|c|c|}
\hline Component & Tannins & Saponins & Alkaloids & Glycosides & Proteins \\
\hline Crude extract & + & + & + & + & + \\
\hline
\end{tabular}

Several authors attributed the inhibitory effects, of the $\alpha$-amylase inhibitor, to the presence of some chemical constituents. Kumar et al. (2011) showed the presence of carbohydrates, steroids, alkaloids, phenolic compounds, flavonoids, saponins and amino acids in their studies about $\alpha$ amylase inhibition in Amaranthus spinosus. Kazeem et al. (2013) found that flavonoids, reducing sugars, saponins, steroids, tannins and terpenoids are presented in ethanol and water extracts of Picralima nitida leaf.

Boivin et al. (1987) and Koh et al. (2010) suggested that catechins in green, oolong and black teas may be responsible for its activity against human salivary $\alpha$-amylase. Phenolic compounds, also, are a large group of structurally diverse naturally occurring compounds that possess at least a phenolic moiety in their structures. Kandra et al. (2004) reported that the main inhibitory effects of the tannins are related to its ability to bind strongly with carbohydrates and proteins. They suggested that the interaction between tannins, such galloylated quinic acid, and human $\alpha$-amylase is correlated with free $\mathrm{OH}$ groups in the tannins that are able to participate in hydrogen bonding. 


\section{Alpha-amylase inhibition assay:}

Percentage of inhibition was measured using the method of Hossain et al. (2008). Fixed amount of porcine pancreatic $\alpha$-amylase was added to different volumes of extract $(100,200,300,450,600 \mu l)$ containing different protein concentration (17.42,35,52.3,87.39 and 104.5mgprot.respectively).All samples were pre-incubated for $15 \mathrm{~min}$ at $37^{\circ} \mathrm{Cin}$ order to form the enzymeInhibitor complex (EI).

Data are shown in table (2) and fig. (1a and 1b), following points could be deduced:

1-Maximum inhibition (100\%) was occurred when $600 \mu$ l (containing 104.5 mg protein) of crude extract was used.

2-Minimum inhibition (19\%) was recorded when $100 \mu \mathrm{l}$ (17.42 $\mathrm{mg}$ protein) of crude extract was used.

3-Finally, it seems that $\mathrm{IC}_{50}$ occurred when $281.79 \mu \mathrm{l}$ (49.1 $\mathrm{mg}$ protein) from crude inhibitor extract was used.

Table (2). Percentage of inhibition using different concentrations of inhibitor.

\begin{tabular}{|c|c|c|c|}
\hline \multicolumn{2}{|c|}{ Inhibitor concentration } & \multirow[b]{2}{*}{$\%$ of inhibition } & \multirow[b]{2}{*}{$\mathrm{IC}_{50}$} \\
\hline $\begin{array}{l}\text { volume of inhibitor } \\
(\mu \mathrm{l})\end{array}$ & $\begin{array}{c}\text { mg protein } \\
\text { inhibitor }\end{array}$ & & \\
\hline 100 & 17.42 & 19.00 & \multirow{5}{*}{$\begin{array}{c}281.79 \mu \mathrm{l} \\
\text { (49.10 mg prot.) }\end{array}$} \\
\hline 200 & 35.00 & 38.90 & \\
\hline 300 & 52.30 & 56.00 & \\
\hline 450 & 87.39 & 79.60 & \\
\hline 600 & 104.50 & 100.00 & \\
\hline
\end{tabular}

$\mathbf{I C}_{50}=$ concentration of the extract required to inhibit $\mathbf{5 0 \%}$ of $\alpha$-amylase activity

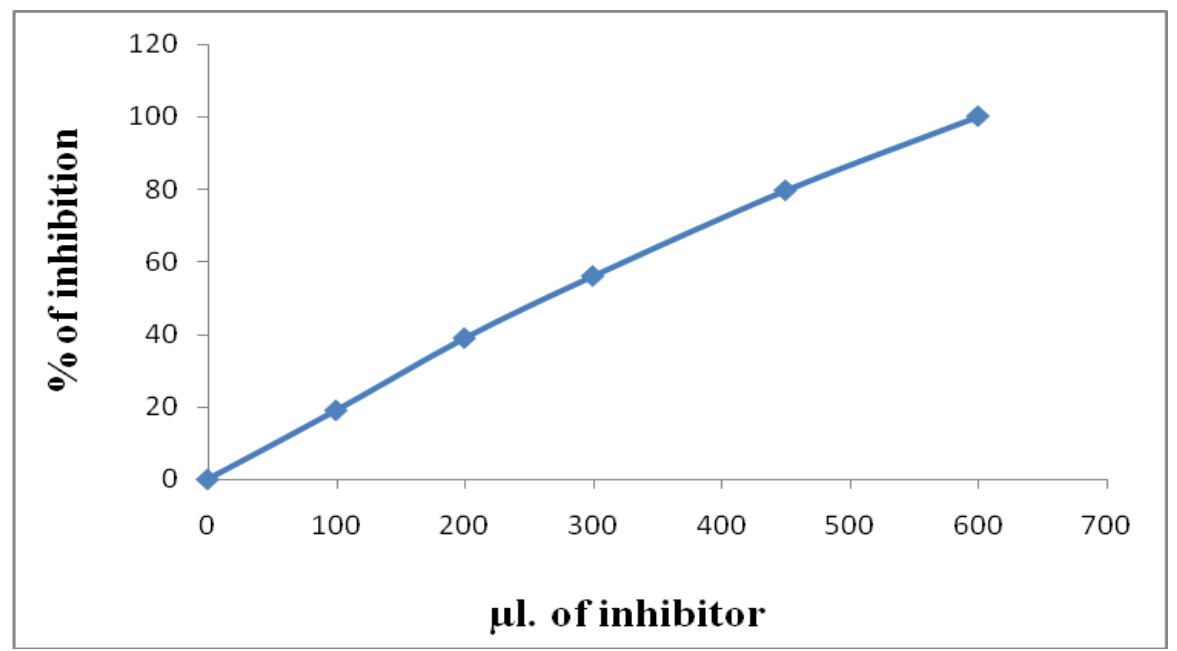

Fig (1a). Percentage of pancreatic $\alpha$-amylase inhibitor 


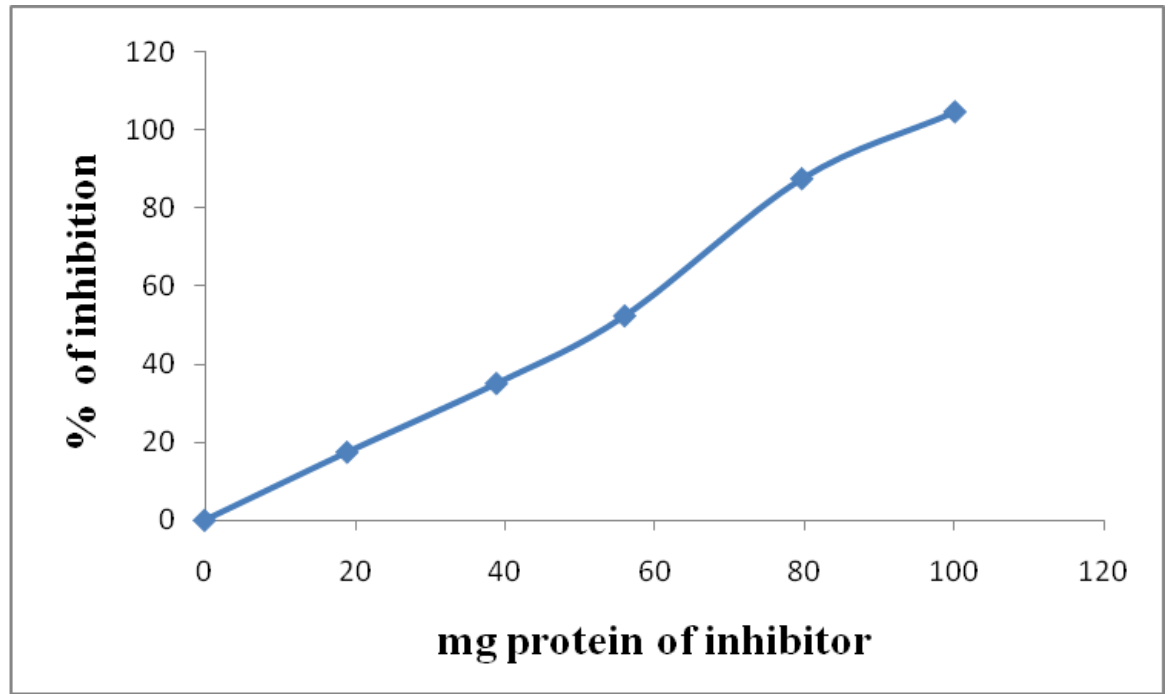

Fig (1b). Percentage of pancreatic $\alpha$-amylase inhibitor

\section{Type of Inhibition:}

$\alpha$-Amylase enzyme activity was determined for porcine pancreatic $\alpha$ amylase and human saliva $\alpha$-amylase by using different concentrations of buffered starch. Enzyme activities were determined in the absence and presence of two levels of $\alpha$-amylase inhibitor [ $(100 \mu \mathrm{l}-17.42 \mathrm{mg}$ prot. and $150 \mu \mathrm{l}-26.13 \mathrm{mg}$ prot.)], then $100 \mu \mathrm{l}$ of porcine pancreatic $\alpha$-amylase containing 4 units of enzyme was used in determination of PPA activity, while $125 \mu \mathrm{l}$ of dilute human saliva was used during the assay of human saliva $\alpha$-amylase activity.

The obtained data were used to realize the relationship between the concentration of substrate $(2.5,6.25$ and $12.5 \mathrm{mg})$ and enzyme activity to ensure the equation of Michaelis and Menten (1913).

To determine the type of inhibition the method of Lineweaver and Burk (1934) was used, by plotting the reciprocal of different substrate concentrations $1 /[\mathrm{S}]$ against the reciprocal of the velocity of enzymatic activity $(1 / v)$, in the absence and in the presence of 100 and $150 \mu \mathrm{l}$ of $\alpha$-amylase inhibitor crude extract, as shown in figures (2) and (3). 


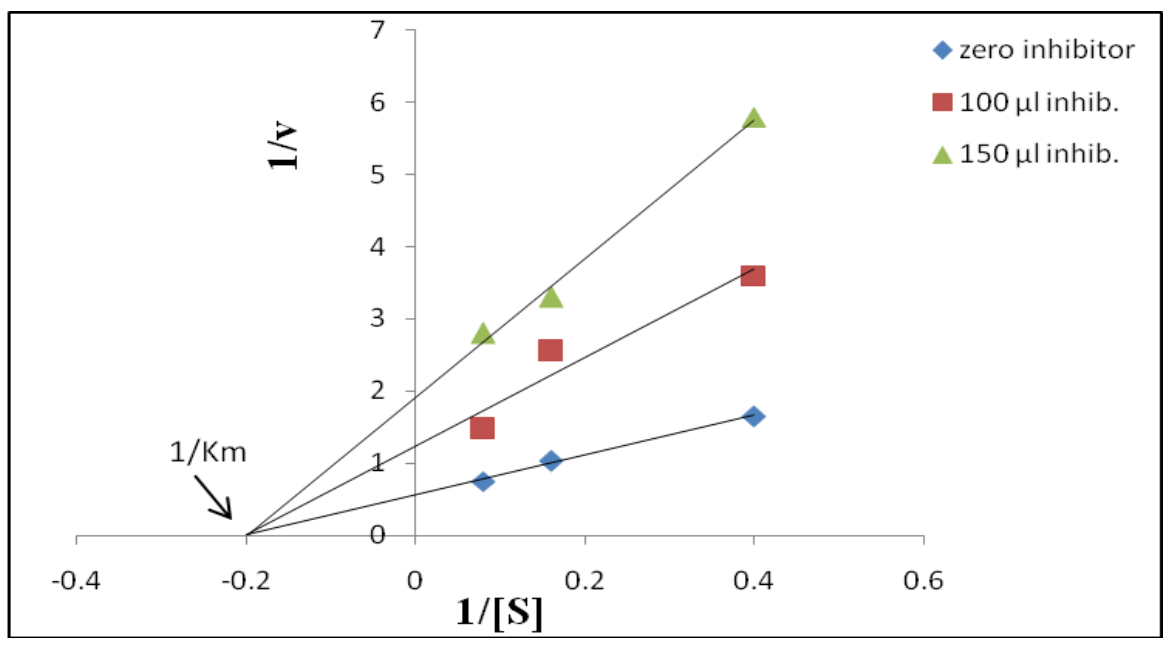

Fig (2). Lineweaver-Burk plot for activity of human saliva $\alpha$-amylase in the absence and in the presence of inhibitors, $100 \mu \mathrm{l}$ and 150 $\mu \mathrm{l}$. The assay digest $(5 \mathrm{ml})$ contained different concentrations of soluble starch $(2.5,6.25$ and $12.5 \mathrm{mg})$, human serum albumin $(0.15 \mathrm{mg})$, Calcium chloride $(0.15 \mathrm{mg})$, sodium phosphate buffer (50 mM, pH 6.9) and enzyme (4 unit), with or without extract. [S] is expressed in $\mathrm{mg} / \mathrm{ml}$; $\mathrm{V}$ is micromoles of glucose equivalents per $\mathrm{ml}$ of enzyme per min.

Our data revealed that the type of inhibition which occurred in used enzymes was non-competitive. Same finding was obtained by Marshall and Lauda (1975), Frels and Rupnow (1985), Subbaramaiah and Sharma (1990), Cengiz et al. (2010), Mogale et al. (2011) and Kazeem et al. (2013).

As reported in Dixon and Webb (1964) inhibitor can influence the enzymatic reaction in such a way that the $\mathrm{K}_{\mathrm{m}}$ is apparently increased or $\mathrm{V}$ is apparently decreased, or both parameters are apparently changed. The first case is known as competitive inhibition, and the second as non-competitive inhibition. Non competitive inhibition has been interpreted for one-substrate reaction as interference with the conversion of the enzyme-substrate complex into the reaction products, while the formation of the complex is not affected. The quantity of active enzyme present is thus apparently less and this is expressed in a decrease in $\mathrm{V}$ and increase in the value of $\mathrm{K}_{\mathrm{m}}$.

$\mathrm{K}_{\mathrm{m}}$ values were: $5 \mathrm{mg}$ and $6.6 \mathrm{mg}$, for human saliva and porcine pancreatic $\alpha$-amylases, respectively. While $V_{\max }$ values were: $2.0,0.83$, and 0.56 , for human saliva $\alpha$-amylase, and were: $0.83,0.50$ and 0.31 , for porcine pancreatic $\alpha$-amylase. 


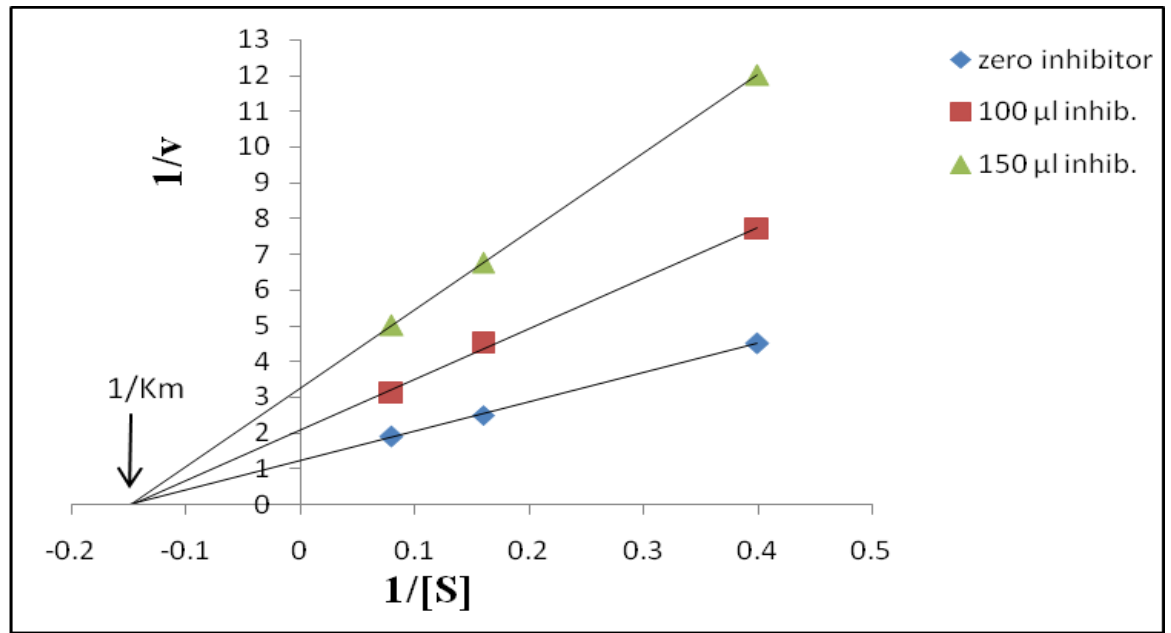

Fig (3). Lineweaver-Burk plot for activity of porcine pancreatic $\alpha$ amylase in the absence and in the presence of inhibitors, 100 $\mu \mathrm{l}$ and $150 \mu \mathrm{l}$. The assay digest $(5 \mathrm{ml})$ contained different concentrations of soluble starch $(2.5,6.25$ and $12.5 \mathrm{mg})$, human serum albumin $(0.15 \mathrm{mg})$, Calcium chloride $(0.15 \mathrm{mg})$, sodium phosphate buffer ( $50 \mathrm{mM}, \mathrm{pH} 6.9)$ and enzyme (4 unit), with or without extract. [S] is expressed in $\mathrm{mg} / \mathrm{ml}$; $V$ is micromoles of glucose equivalents per $\mathrm{ml}$ of enzyme per min.

The determination of the Stoichiometry of the crude extract: Crude extract inhibitor, extracted from white Kidney beans $(0.6 \mathrm{ml}$, contg. $107.52 \mathrm{mg}$. prot.) was pre-incubated with porcine pancreatic alphaamylase (100 $\mu \mathrm{l}$ contg. 4 unit of enzyme) in digests containing acetate-citrate buffer, $\mathrm{pH} 5.5,6.7 \mathrm{mM}, 0.15 \mathrm{mg}$ human serum albumin and $0.15 \mathrm{mg}$ calcium chloride, for $15 \mathrm{~min}$ at $37^{\circ} \mathrm{C}$. Residual alpha-amylase activity then was assayed using the lodine staining method, after the addition of soluble starch solution buffered with phosphate buffer (pH6.9,50 mM). Finally, digests incubated at $37^{\circ} \mathrm{C}$ for different periods: $15,30,45,60,90,105$ and $120 \mathrm{~min}$, (Fig.4).

Data obtained showed a considerable increase in percentage of inhibition. About $20 \%$ of inhibition was obtained after 15 min from the beginning of incubation. Further increase was occurred by increasing period of incubation (nearly $90 \%$ ) when the digest was incubated for about 60 min. It could be seen also that, elongation of incubation period resulted in a considerable decrease in inhibition percentage. Fig (4) showed that incubation for 90, 105 and 120min led to an inhibition percentage of about 50, 40 and $35 \%$ respectively. It seems that a reversible reaction was occurred after the formation of the Enzyme-Substrate-Inhibitor complex as illustrated by Bergmeyer (1978). As shown in Fig (4), the rate of reaction began to be constant, after 120 min from the beginning of incubation. 


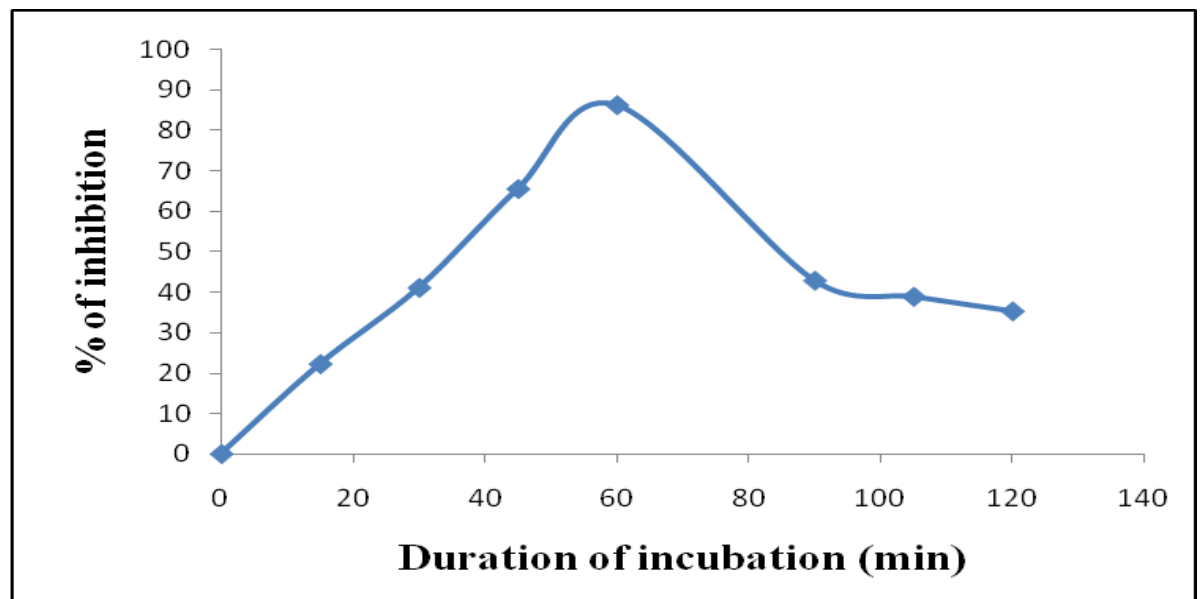

Fig (4). Effect of time of incubation on the activity of $\alpha$-amylase inhibitor extracted from white kidney bean.

Our results did not agree with those obtained with Marshall and Lauda (1975), where they obtained the maximum of inhibition (45\%) after a period of $60 \mathrm{~min}$ from the beginning of incubation. This may be due to the purification of the inhibitor, as they reported, by using 3 different steps of Chromatography: DEAE Cellulose, Sephadex G- 100 and CM- Cellulose, while crude inhibitor was used during this investigation.

\section{REFERNCES}

Alberti, K.G.M.M. and Zimmet, P.Z. (1998). WHO consultation. Definition, diagnosis and classification of diabetes mellitus and its complications. Part 1: Diagnosis and classification of diabetes mellitus - provisional report of a WHO consultation. Diabetic Med, 15: 539.

Bergmeyer, H.U. (1978). Principle of Enzymatic Analysis. Veralag Chemie, Weinheim, New York.

Bowman, D.E. (1945). Amylase inhibitor of Navy beans. Science, 102: 358.

Bird, R. and Hopkins, R.H. (1954). The action of some a-Amylases on amylase. Biochem. J., 56: 86.

Bo-Linn, G.W.; Santa Ana, C.A.; Morawski, S.G. and Fordtran, J.S. (1982). Starch blockers- their effect on calorie absorption from a high-starch meal. N. Engl. J. Med., 307: 1413.

Boivin, M.; Zinsmeister, A.R., Go, V.L. and DiMagno, E.P. (1987). Effect of a purified amylase inhibitor on carbohydrate metabolism after a mixed meal in healthy human. Mayo Clin Proc, 62: 249.

Brugge, W.R. and Rosenfeld, M.S. (1987). Impairment of starch absorption by a potent amylase inhibitor. Am. J. Gastroenterol, 82: 718.

Carlson, G.L.; Li, B.U.; Bass, P. and Olsen, W.A. (1983). A bean alphaamylase inhibitor formulation (starch blocker) is ineffective in man. Science, 219: 393. 
Cengiz, S.; Cavas, L. and Yurdakoc, K. (2010). Alpha-amylase inhibition kinetics by caulerpenyne. Medit. Mar. Sci., 11 (1): 93.

Danaei, G.; Finucane, M.M. and Luy. (2011). National, regional, and global trends in fasting plasma glucose and diabetes prevalence since 1980: Systamatic analysis of the health examination survey and epidemiological studies with 370 country-years and 2.7 million participants. Lancet; 378: 31.

Dixon, M. and Webb, E.C. (1964). Enzymes, $2^{\text {nd }}$ edition, Longmans, London.

Duke, J.A. (1985). Handbook of Medicinal Herbs. CRC Press, Boca Raton, Florida, pp. 362.

Frels, J.M. and Rupnow, J.R. (1985). Characterization of two a-amylase inhibitors from black bean (Phaseolus vulgaris). Journal of Food Science, 50: 72.

Garrow, J.S.; Scott, P.F.; Heels, S.; Nair, K.S. and Halliday, D.A. (1983). A study of starch blockers in man using 13C-enriched starch as a tracer. Hum Nutr Clin Nutr, 37: $301-5$.

Harbone, J.B. (1988). Phytochemical methods, $2^{\text {nd }}$ ed. Published in U.S.A. by Chapman and Hall 29, West $35^{\text {th }}$ street, New York.

Hollenbeck, C.B.; Coulston, A.M.; Quan, R.; Becker, T.R.; Verman, H.J.; Stevenson, D.K. and Reaven, G.M. (1983). Effect of a commercial starch blocker preparation on carbohydrate digestion and absorption: in vivo and in vitro studies. Am J Clin Nutr, 38: 498.

Hernandez, A., and Jaffé, W.G. (1968). Inhibitor of the pancreatic amylase in beans (Phaseolus vulgaris).Acta Cient. Venez, 19: 183.

Holman, R.R.; Paul, S.K. and Bethel, M.A. (2008). 10-years follow-up of intensive glucose control in type 2 diabetes. N. Engl. J. Med. 359:1577.

Hossain, S.J.; Tsujiyama, I.; Takasugi, M.; Islam, M.A.; Biswas, R.S. and Aoshima, H. (2008). Total Phenolic Content, Antioxidative, Antiamylase, Anti-glucosidase, and Antihistamine Release activities of Bangladeshi Fruits, Food Sci. Technol. Res., 14: 261.

Kandra, L.; Gyemant, G.; Zajacz, A. and Battab, G. (2004). Inhibitory effects of tannin on human salivary $\alpha$-amylase. Biochem. Biophys. Res. Commun, 319: 1265.

Kazeem, M.L.; Ogunbiyi, J.V. and Ashafa, A.O. (2013). In vitro studies on the inhibition of $\alpha$-amylase and $\alpha$-glucosidase by leaf extract of Picralima nitida (Stapf). Tropical Journal of Pharmaceutical Research, 12(5): 719.

Koh, L.W.; Wong, L.L.; Loo, Y.Y.; Kasapis, S. and Huang, D. (2010). Evalution of different teas against starch digestibility by mamamalian glycosidases. J. Agric. Food Chem., 58: 148.

Kumar, B.S.A.; Lakshman, K.; Nandeesh, R.; Kumar, P.A.A.; Manoj, B.; Kumar, V. and Shekar, S. (2011). In vitro alpha-amylase inhibition and in vivo antioxidant potential of Amaranthus spinosus in alloxan-induced oxidative strees in diabetic rats. Saudi Journal of Biological Sciences, 18: 1.

Layer, P.; Carlson, G.L. and DiMango, E.P. (1985). Partially purified white bean amylase inhibitor reduces starch digestion in vitro and inactivates intraduodenal amylase in humans. Gastroenterology, 88: 1895. 
Layer, P.; Rizza, R.A.; Zinsmeister, A.R.; Carlson, G.L. and DiMango, E.P. (1986). Effect of a purified amylase inhibitor on carbohydrate tolerance in normal subjects and patient with diabetes mellitus. Mayo Clin Proc, 61: 442.

Lineweaver, H. and Burk, D. (1934). Determination of $\mathrm{K}_{\mathrm{m}}$. J.Am. Chem.Soc. 56: 658. [C.F. Principles of enzymatic analysis. Edit by Hans Ulrich Bergmeyer. Verlage Chemie. Weinheim. New York, 1978, 39].

Lowry, O.H.; N.J. Rosenbrough; A.L. Farr and R.I. Randall, (1951). Protein measurement with the Folin-Phenol reagents. J. Biol. Chem., 193: 265.

Marshall. J. J. and Lauda, C. M. (1975), Purification and properties of Phaseolamin, an inhibitor of $\alpha$-amylase, from the kidney bean, Phaseolus vulgaris. The journal of Biological Chemistry, 250: 8030.

McDougal, G.L. and Stewart, D. (2005). The inhibitory effects of berry polyphenols on digestive enzymes. Biofactors, 23: 189.

Michaelis, L. and Menten, M.L. (1913). Die Kinetik der Invertinwirkung. Biochem Z 49: 333.

Mogale, M.A.; Lebelo, S.L.; Thovhogi, N.; De Freitas, A.N. and Shai, L.J. (2011). a-Amylase and a-glucosidase inhibitory effects of Sclerocarya birrea [(A.Rich.) Hochst] subspecies caffra (Sond) Kokwaro (Anacardiaceae) stem-bark extracts. African Journal of Biotechnology, 10 (66): 15033.

Moreno, J.; Atabella, T. and Chrispeels, M.J. (1990). Characterization alphaamylase inhibitor, a lectin-like protein in the seeds of Phaseolus vulgaris. Plant Physiol., 92: 703.

Puls, W. and Keup, U. (1973). Influence of an -amylase inhibitor (BAY d 7791) on blood glucose, serum insulin and NEFA in starch loading tests in rats, dogs and man. Diabetologia, 97: 101.

Somogyi, M. (1952). Notes on sugar determination. J. Biol. Chem., 195:19.

Subbaramaiah, K. and Sharma, R. (1990). Characterization of $\beta$-amylase from Sinapis Alba cotyledons. Phytochemistry, 29: 1417.

Tundis, R.; Loizza, M.R. and Minchini, F. (2010). Natural products as $\alpha-$ amylase and $\alpha$-glucosidase inhibitors and their hypoglycaemic potential in the treatment of diabetes. Med. Chem., 10: 315.

Weiner, D.; Levy, Y.; Khankin, E.V. and Reznick, A.Z. (2008). Inhibition of salivary amylase activity by cigarette smoke aldehydes. Journal of Physiology and Pharmacology, 59:727.

Yamaguchi, H. (1991). Isolation and characterization of subunits of Phaseolus vulgaris $\alpha$-amylase inhibitor. J. Biochem. 100: 785. 
Tadros, L. K. et al.

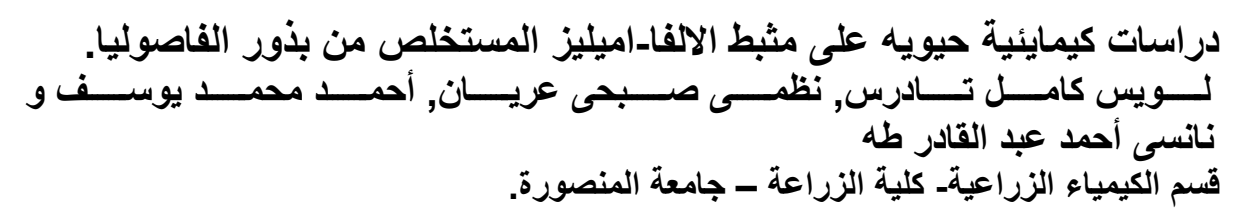

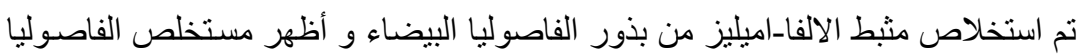

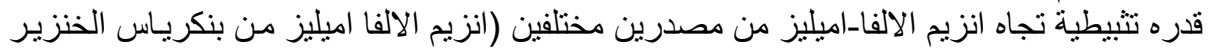

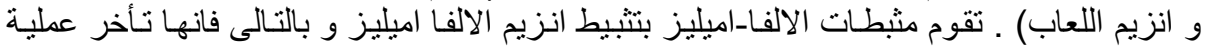

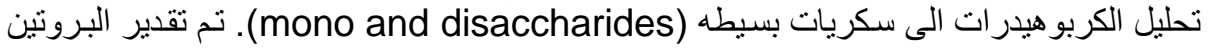

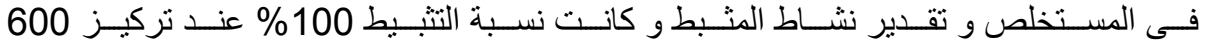

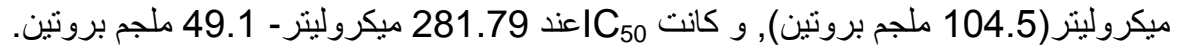

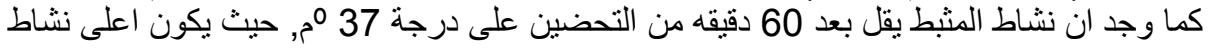
عند 60 دقيقه (حوالى 90\%) . و و عند تقدير نوع التثبيط وجد ان المثبط يثبط انزيمات الالفا-اميليز

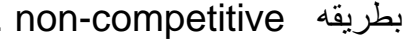

